\title{
The Winteraceae of the Old World. VII. Zygogynum in the Solomon Islands (incl. Bougainville)
}

\author{
W. Vink ${ }^{1}$
}

Key words

Solomon Islands

Winteraceae

Zygogynum

\begin{abstract}
A review of the character distribution in the Zygogynum representatives from the Solomon Islands (and Bougainville) shows a rather wide variability in ranges of numbers and sizes, often with distinct differences between islands or altitudinal ranges. However, the morphology is rather uniform. The four species recognised by A.C. Smith had to be synonymised, but a new taxon deserved recognition. The name Bubbia is explained.
\end{abstract}

Published on 19 December 2014

\section{INTRODUCTION}

The first Zygogynum species described from the Solomon Islands is Bubbia haplopus B.L.Burtt (1936). In his monumental works on the Papuasian plants, Smith (1942) transferred this species from Bubbia to the other Van Tieghem genus, Belliolum, and described three more species from this area. The materials available to Smith were, however, very incomplete, and several characters could not be established; next to leaf size, minor differences had to be used to define these taxa. Although after World War II the number of collections has increased enormously, mainly due to the activities of the Forestry Department at Honiara, the representation of open flowers and ripe fruits is still very poor, frustrating the study of the regional variability. Although Burtt (1936) already united Bubbia and Belliolum, Smith (1942: 438, 1943b: 151) tentatively retained the division. Later both were sunk into Zygogynum (Vink 1985).

Although the Solomon Islands Zygogynum specimens can have a very different look because of the large range in leaf size, they are otherwise very similar if compared with the species from New Caledonia and New Guinea.

\section{GENERAL DESCRIPTION}

The leaves are chartaceous with adaxially an impressed midrib. The partial inflorescences consist of solitary flowers and/ or triads (with one exception; see later). The flowers are protogynous. The thin calyx is cup-shaped with its margin mostly not ruptured. The outer petals are free; the inner petals often have (mostly apical) irregular thickenings. The stamens terminate in a relatively large sterile apex. The stigma is apical on the free carpels. The fruitlets are hard berries with a relatively thick wall, but almost lacking pulpa. The exotestal seeds are straight, with flat mutual sides and a minutely textured surface on the free outer sides.

The differences within this Solomon Islands material are almost exclusively caused by a variation in numbers and sizes.

\footnotetext{
Naturalis Biodiversity Center, section Botany, P.O. Box 9517, 2300 RA Leiden, The Netherlands; vinkmen@xs4all.nl.
}

\section{CHARACTERS AND THEIR VARIABILITY}

\section{Leaves}

Except for size, the leaves are very uniform with the blade chartaceous, the midrib impressed above and prominent below. On the lower side of the blade the grey to white alveolar material covers only the stomata or unites these into small strings or clusters; the stomata are also present over the secondary nerves, or less dense to lacking over the thickest parts of the largest nerves.

Within a collection leaf size can vary substantially. As the range of small-leaved specimens can easily fall within the range of large-leaved specimens, the sizes of the largest leaf of a collection were used for the following analysis.

There is no overall relation between leaf size and altitude. The range in altitude is $0-1900 \mathrm{~m}$. The longest leaves $(26 \mathrm{~cm})$ are found on Bougainville Island, at 690-800 m altitude and on Santa Isabel $(27 \mathrm{~cm})$ in the lowlands. The widest leaves are found both at sea level and at $800 \mathrm{~m}$. At the latter altitude the variation in largest leaf length $(9.5-26.5 \mathrm{~cm})$ and largest leaf width $(3.5-10 \mathrm{~cm})$ is so wide that it even covers the ranges at higher (up to $1900 \mathrm{~m}$ ) and lower (down to sea level) altitudes.

It could be that the more varied terrain configuration on Bougainville I. (for a description, see Kajewski 1946, Scott et al. 1967) distorts a direct relation between leaf size and altitude by offering more sheltered locations at mid-altitudes. Kolombangara Island, however, consists of a single regularly formed volcanic cone (Thompson \& Hackman 1969) and on its slopes such a (rather weak) relation is found indeed. Like from Bougainville I., thirteen collections are available.

Seven of these are from 60-330 m altitude; they show a largest leaf width of $5-6.5 \mathrm{~cm}$; the six collections from 360-1650 m altitude have largest leaf widths of $3-4.5 \mathrm{~cm}$. The inflorescences also show a diminution: in the first group of specimens they have 1- and 3-flowered partial inflorescences, the group from higher altitudes has only solitary flowers.

At the highest altitudes the leaves are not or only slightly thicker than at sea level.

\section{Inflorescences}

The inflorescences are terminal to the twig, sometimes on a leafless short shoot axillary to a lower bract scar of an older 
inflorescence. In the herbarium material the inflorescences are usually very incomplete, but they nevertheless show that partial inflorescences consist of solitary flowers or of triads. There is one exception: in the single specimen known of $Z$. whitmoreanum the partial inflorescences are 6-8-flowered.

As mentioned above, at least on Kolombangara I. there seems to be a correlation between absence or presence of triads with altitude and with largest leaf width. Other cases, however, show that there is a gradual transition between absence and presence of triads. Examples are large-leaved specimens from Bougainville I. In Kajewski 1994 (leaves up to $26 \times 10$ $\mathrm{cm})$ three inflorescences have triads and one inflorescence has 5 solitary flowers; on the other hand, NGF 31343 (leaves up to $26.5 \times 7.5 \mathrm{~cm}$ ) has only one triad and 11 solitary flowers in four inflorescences.

In mixed inflorescences the solitary flowers and the triads are usually of the same length.

As in most other species of Zygogynum, in triads flowering is centrifugal and the pedicels of the lateral flowers are usually longer than that of the central flower. If only one lateral flower is developed, this may be overtopped by the central flower. Flowering sequence in an inflorescence could only once be observed, in BSIP 4279 (from San Cristoval); there the order was centrifugal except for the lowest flower that was wide open like the top flowers.

The very small bracts are fugacious.

\section{Flowers}

The number of flowers available for dissection is extremely low. To avoid destruction of all material often only one flower(bud) of a specimen could be used. From the cases where two or three flower(bud)s could be studied some insight in the variation within and between specimens could be gained (Table 1). Of nine collections two flower(bud)s were dissected and the variation between these two buds in petal numbers was $(0-) 1$ or $2(-3)$, in stamen numbers $1-3(-4)$, and in carpel numbers $0-4$. Of three specimens three flowers were dissected and here the variation was: in petals 1 , in stamens $2-7$, and in carpels $0-1$. Compared to this, the variation between the specimens is generally distinctly larger: in all specimens studied petals number $7-22$, stamens $8-36$, carpels $1-8$, and ovules $13-38$.

Such variations are comparable to those found elsewhere in the genus. For instance, in Z. pancheri subsp. pancheri the intraindividual ranges of differences are (2-6 flowers per collection; $\mathrm{n}=13$ ): petals $0-6$, stamens $0-9$ (and 19), carpels $0-2$ (or $3)$; the inter-individual ranges $(n=20)$ are: petals numbering 12-25, stamens $19-45$, carpels $3-9$.

The thin calyx is usually cup-shaped with a 2(-3)-tipped but otherwise entire margin; in almost all other Zygogynum species

Table 1 Flower parts: Observed numbers (N) and variation (V) within specimens of Zygogynum haplopus.

\begin{tabular}{|c|c|c|c|c|c|c|}
\hline \multirow{2}{*}{$\begin{array}{l}\text { Number of flowers } \\
\text { dissected } \\
\text { per specimen }\end{array}$} & \multicolumn{2}{|c|}{ petals } & \multicolumn{2}{|c|}{ stamens } & \multicolumn{2}{|c|}{ carpels } \\
\hline & $\mathrm{N}$ & $\mathrm{V}$ & $\mathrm{N}$ & $\mathrm{V}$ & $\mathrm{N}$ & V \\
\hline 2 & 8,10 & 2 & 15,18 & 3 & 3,4 & 1 \\
\hline 2 & 11,12 & 1 & 15,16 & 1 & 3,5 & 2 \\
\hline 2 & 6,8 & 2 & 8,9 & 1 & 2 & 0 \\
\hline 2 & 14 & 0 & 23,27 & 4 & 9,13 & 4 \\
\hline 2 & 9,11 & 2 & 17,19 & 2 & 2,5 & 3 \\
\hline 2 & 7,8 & 1 & 16,17 & 1 & 2,3 & 1 \\
\hline 2 & 9,10 & 1 & 15,18 & 3 & 1 & 0 \\
\hline 2 & 7,9 & 2 & 11,14 & 3 & 1 & 0 \\
\hline 2 & 8,11 & 3 & 24,26 & 2 & 3,5 & 2 \\
\hline 3 & $7-8$ & 1 & $10-12$ & 2 & 1 & 0 \\
\hline 3 & $7-8$ & 1 & $15-22$ & 7 & $2-3$ & 1 \\
\hline 3 & $7-8$ & 1 & $13-18$ & 5 & 1 & 0 \\
\hline
\end{tabular}

the calyx is ruptured upon opening of the flower and thus becomes seemingly lobed. In very young stages the calyx is closed by its overlapping lobes; if there are two lobes, these are orientated perpendicular to the subtending bract.

The corolla has no definite petal number: the full range observed is $7-22$, but most common is $8-14$. No correlation with other characters could be found (material with the widest leaves, $8.5-10 \mathrm{~cm}$, is not in flower).

The petals can be arranged in alternating 'whorls' of three or of four (decussate) members. In Waterhouse B. 537 (unidentified, Bougainville I.) both situations were found: a flower with 8 petals (4 + 4; calyx 2-tipped) and another one with 11 petals $(3+3+5$; calyx 3-tipped). In Kajewski 2630 (B. gracile from Guadalcanal) one of two tiny buds contained 7 petals in a quincuncial arrangement, the other bud had 6 petals arranged in two whorls (the 7th more inwards). In Brass 3063 (B. gracile from San Cristoval) one bud had its 4 outer petals next to the calyx; in another bud the 9 petals were apparently in one row adjacent to the calyx, resembling a stamen arrangement.

The size of the petals shows a wide variation, but as a rule the length is only $1.5-3$ times the width. The outer petals tend to be slightly longer and more distinctly broader than the inner ones. As in many other species of this genus, parts of the inner surface are in sicco often rather roughly papillate.

The inner petals often show on their adaxial side one or a few ribs and local - especially apical - irregular thickenings. In a bud of Kajewski 1680 (type of Belliolum burttianum) (Fig. 1e) the stamens were overtopped by both the carpels and the petals, there even being a free space between the top of the carpels and the ceiling-formed by the overlapping or slotted petal apices. A similar case was found in BSIP 6244. This shows that the impressions and thickenings of (at least the distal part of) the adaxial side of the petals are not the result of a pressure exercised by the expanding stamens. In a bud of BSIP 2514 (New Georgia) the apical thickenings of the inner petals were interlocking with each other, not with the stamens. Further, in rare cases (in BSIP 4279, Fig. 1c; BSIP 19355) not only the inner petals, but also two of the four outer petals showed a form of thickening.

It is surprising that these petal thickenings are usually finely papillate, as are the stamens (the thecae are not papillate). As no chewing damage was observed in these parts of the flowers, a function of food-body comparable to that in Zygogynum (Exospermum) stipitatum (Thien et al. 1990) is not very probable. The presence of these thickenings is irregular: not in all specimens, not in all flowers of a specimen, and between flowers varying from in none to in all petals except the two outermost ones.

In a few collections the material was dried at the right time to show that the inner petals are erect when the outer petals are spreading to recurved (Fig. 1b). In quite a number of protogynous Zygogynum species in New Caledonia (Z. baillonii, bicolor, pancheri, stipitatum, vieillardii) such an arrangement occurs on the first flowering day (Pellmyr et al. 1990, Vink 1993 pl. 24: 6 \& 7) when the flowers are female; there the inner petals spread on the second day when the anthers open.

The stamen is very variable, but in general it is a more or less flattened organ with the thecae sunken in the lateral sides at variable heights, with the part below the thecae (filament) narrowed or not, the part above the thecae (sterile apex) for varying stretches ovate to oblong and usually ending acutish. The stamen is often somewhat curved out dorsally, sometimes strongly so below the thecae. The thecae can be touching, but they are usually slightly to widely separated (Fig. 2a, b); they open dorso-laterally or laterally with a vertical slit. 
No name has been invented for the part of the stamen distally from the thecae. Canright (1952) circumvents this as follows: "Elongation of the apices (called 'connective appendages' by most taxonomists)"; Endress \& Hufford (1989) use the phrase "anther connective protrusion"; Endress \& Doyle (2009) discuss "an extended connective apex" and Friis et al. (1986) a "connective ... expanded at the apex". In Annonaceae literature are found "connective apex" (Maas \& Westra 2003) and "connective prolongation" (Mols \& Keßler 2003). In Compositae literature the terminology "apical appendage" is used. Friis et al. (1986) describe a "fleshy and almost cylindrical connective that is slightly expanded at the apex." For Winteraceae Endress \& Hufford (1989) use "connective protrusion". However, it is more appropriate to name the staminal parts proximally (filament) and distally (sterile stamen apex) from connective and thecae with independent names to avoid suggestions of morphological or historical implications. Hence, the term 'sterile apex' will be used here.

The number of stamens ranges from 8-36. There is no correlation with the number of petals; the highest number of stamens (36) was found in an 11-petalled as well as in a 22-petalled flower. Within a flower the length of the stamens can vary very little to rather considerably, even within orthostichies. As the floral appendages are not arranged in a fixed pattern, but according to the principle of first available space (Hofmeister 1868: 508, Vink 1970, Leins \& Erbar 1997, Kirchoff 2003, for history), the form and size of a location on the floral apex available for the development of a stamen varies and with it the size of a stamen.

From a few observations in herbarium material the impression is gleaned that in the female flower stage the stamens more or less equal the carpels in length, but outsize the latter in the male stage.

Except for the thecae the stamens are finely papillate as are the adaxial thickenings of the inner petals. Papillose stamens are also described for Austrobaileya scandens C.T.White by Endress (1980).

In the transitional area from petals to stamens not infrequently deviating structures are found, e.g. a small petal, a small petal with one theca, or a very large stamen, showing that the boundary between petals and stamens as well as the relation between form and size are not always very strict. Once, in RSS 1192, a large stamen was found replacing the carpels (Fig. 2c). Pollen is released in tetrads (Bailey \& Nast 1943a, f. 11).

The carpels are free, as long as wide (Fig. 2e), less often longer than wide (Fig. 2d). Usually their number is $1-3$, less often up to 5 or 8 ; in the single specimen of $Z$. whitmoreanum 10-13 carpels were found.

Impressions on the lateral sides, made by the highest stamens, disappear postflowering when the carpels start to expand. The stigma is extending over the entire length of the carpel apex (except in Z. whitmoreanum) without descending at the adaxial side of the carpel, although the placenta extends further down on that side; this was described by Bailey \& Nast (1943b, f. 19) as an unconformity between the orientation and the extension of the placental ridges and the stigmatic crest. The ovules are initiated in a single line. In later stages they are closely packed together on the almost not enlarged placenta, often pressing each other out of line (Fig. 2f). Elongated funicles placing ovules beyond the crowd, as found in other species like Z. stipitatum, were only once observed (Kajewski 16580).

Once (in BSIP 5152) a twin carpel was seen; its common locule contained a double set of placentas, $\mathrm{V}$-shaped towards their junction, totalling 46 ovules.

In BSIP 3751 (New Georgia) the space between the apices of the stamens and carpels and of the inwardly folded, thickened petals was filled with flimsy dark brown material, suggestive of dried exudate (from the carpels?). Stigmatal exudate in a still closed flowerbud was also observed in Z. vieillardii (Vink
1977: 233). This is in line with the observation by Thien (1980: 8 ) that in the protogynous flowers of $Z$. baillonii the stigmas are already receptive when the flowers open and fluid is secreted at the apex of the (there syncarpous) gynoecium. A similar observation is made by Gottsberger et al. (1980: 24) for Drimys brasiliensis. For New Guinea Drimys, Thien not only reports fluid from the stigmas, but also from the top of the stamens. On the other hand, this author also explicitly states that no stigmatic fluids have been noted in the flowers of Zygogynum (Belliolum) pancheri and of $Z$. pomiferum ssp. balansae (Thien 1980: 6, 9). Stigmas of Pseudowintera colorata are reported to be moist (Godley \& Smith 1981: 153) or to produce minute quantities of secretion only (Lloyd \& Wells 1992: 84).

Only in Schodde \& Craven 3718 (Bougainville, small-leaved) several times an apical residuum was observed between the immature fruitlets. Such a residuum was up till now reported

-for the American species Drimys winteri:

In Drimys: "The carpels are usually arranged in a single whorl around the blunt apex of the torus, ..." (Smith 1943a)

In Drimys winteri: "The apex above the carpels is about $112 \mu$ in diameter, with a range of 80 to $200 \mu$." (Tucker 1959).

In Drimys winteri: "... the floral apex, which can be recognised as an apical residuum after all appendages have been formed." (Tucker 1965).

- for Zygogynum stipitatum (Sampson \& Tucker 1978);

-in one out of two buds from a specimen of Zygogynum semecarpoides (Vink1983);

However, very minute apical residua up to the size of a carpel base were found as isolated cases in several flowers of New Caledonian taxa, e.g. of Zygogynum amplexicaule and of Z. pancheri (Vink, unpubl.). Whereas the absence or presence of an apical residuum appears to be structural in Drimys (Vink 1970: 263), its occurrence in Zygogynum is accidental.

Another deviation is the complete absence of carpels in the single flower dissected of Corner RSS 1192 (Kolombangara, $1650 \mathrm{~m}$ alt.), that otherwise had a normal range of other appendages: 7 petals and 12 stamens. However, the highest stamen was distinctly larger that the other ones (Fig. 2c).

\section{Fruitlets}

The fruitlets are hard (sub)globose berries, varying in size from 12-25 mm diam, red when ripe, with a rounded to obconical base or with a short but distinct stipe, with a stigma mostly distinct and subapical or apical, and with a (rather) thick fruit wall with scattered nests of brachysclereids. Ripe fruits are scarce in the herbarium material, but ripe seeds were found both in the smaller, relatively thin-walled fruits and in the largest, thickwalled fruits. The placenta is almost not enlarged and forms only a ridge on the ceiling of the locule. The pulpa is also very poorly developed and consists of low ridges on the fruit wall, outlining the contact zones of the seeds.

\section{Seeds}

Submature seeds are somewhat shrivelled, (shining) black, and minutely pusticular and/or ribbed. When the seeds are full-sized, they are closely stacked (Fig. $2 \mathrm{~g}$ ), with large flat areas where pressed against each other, but on the convex free outer sides the surface is similarly minutely textured; in addition the epidermal cells have become very distinct, dull, and (light brownish) grey when dry. Often a significant part of the seeds is abortive.

For description of the wood anatomy, see Carlquist 1983. 


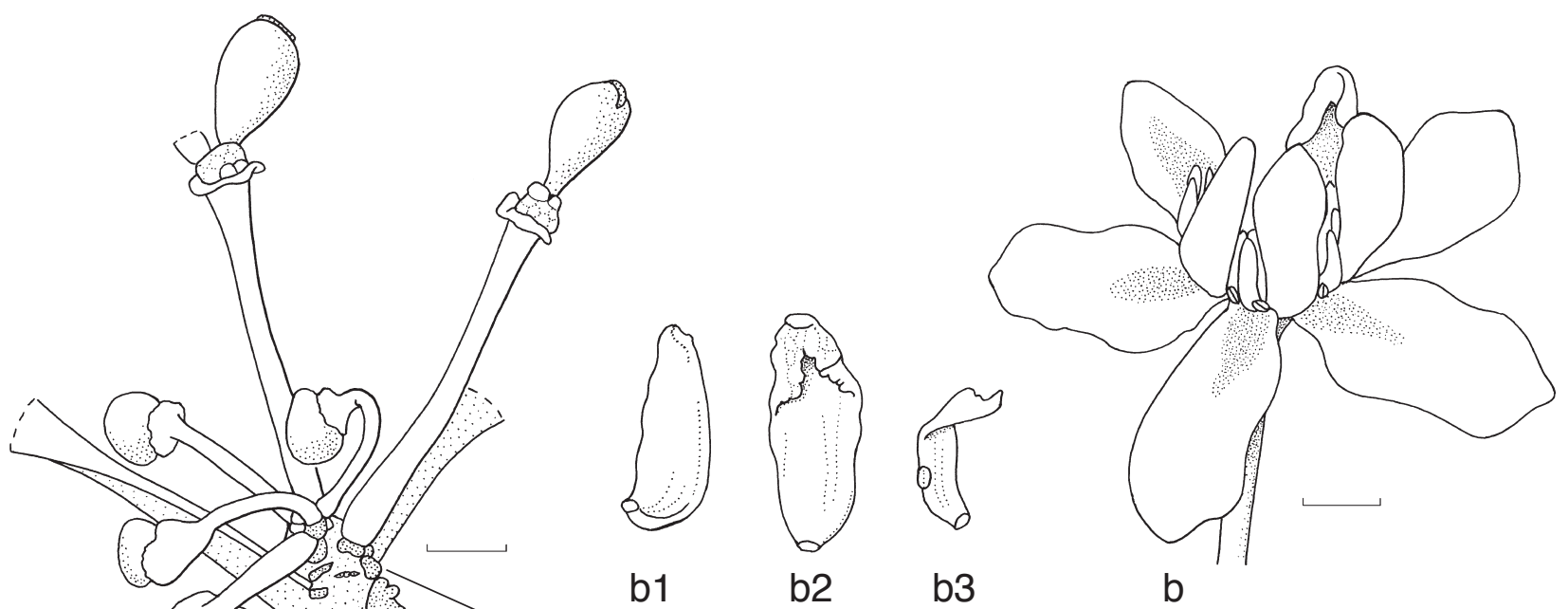

a

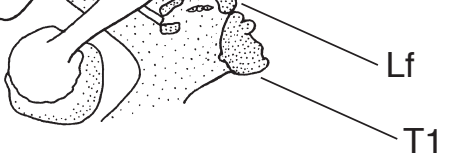

b1
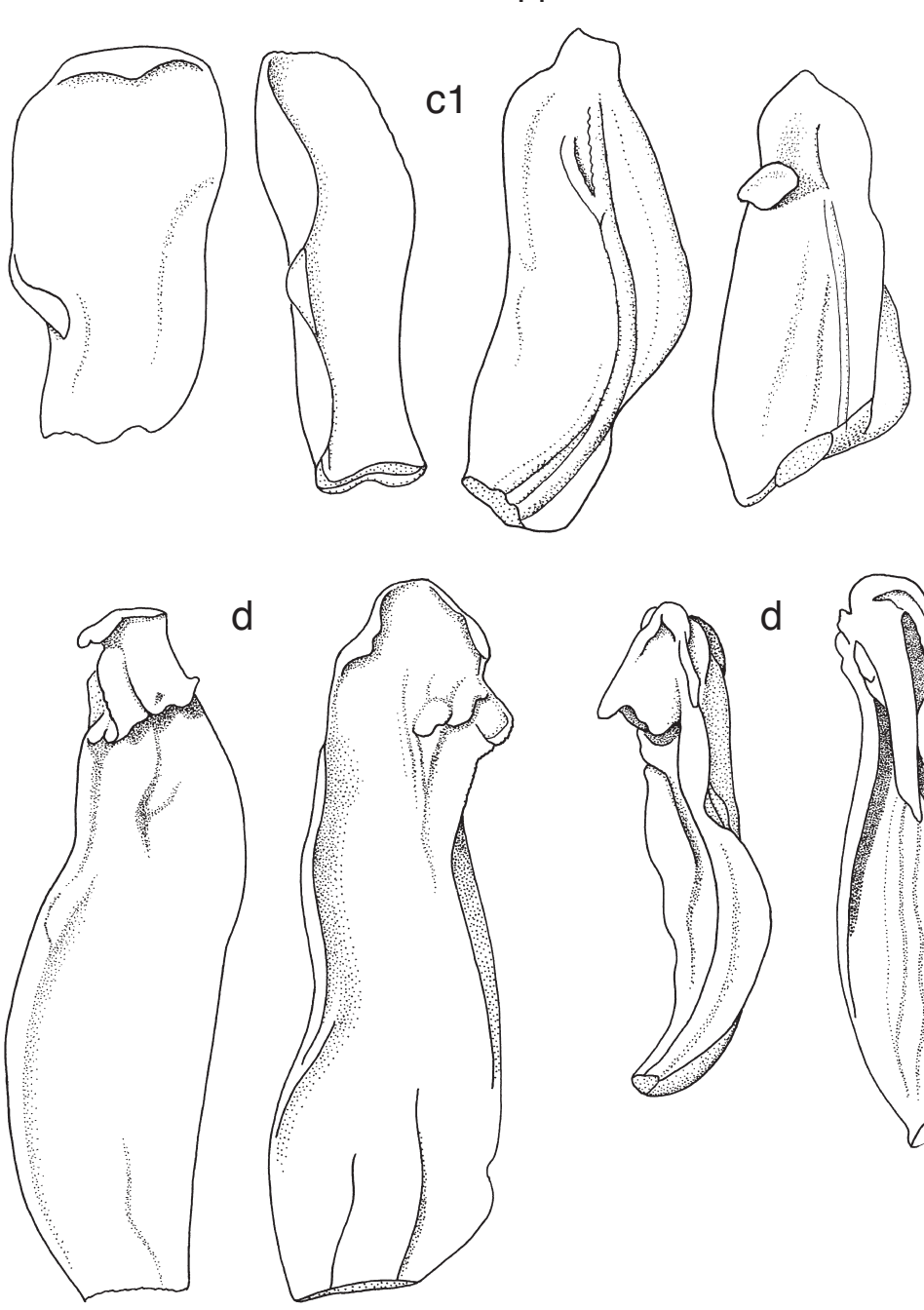

d
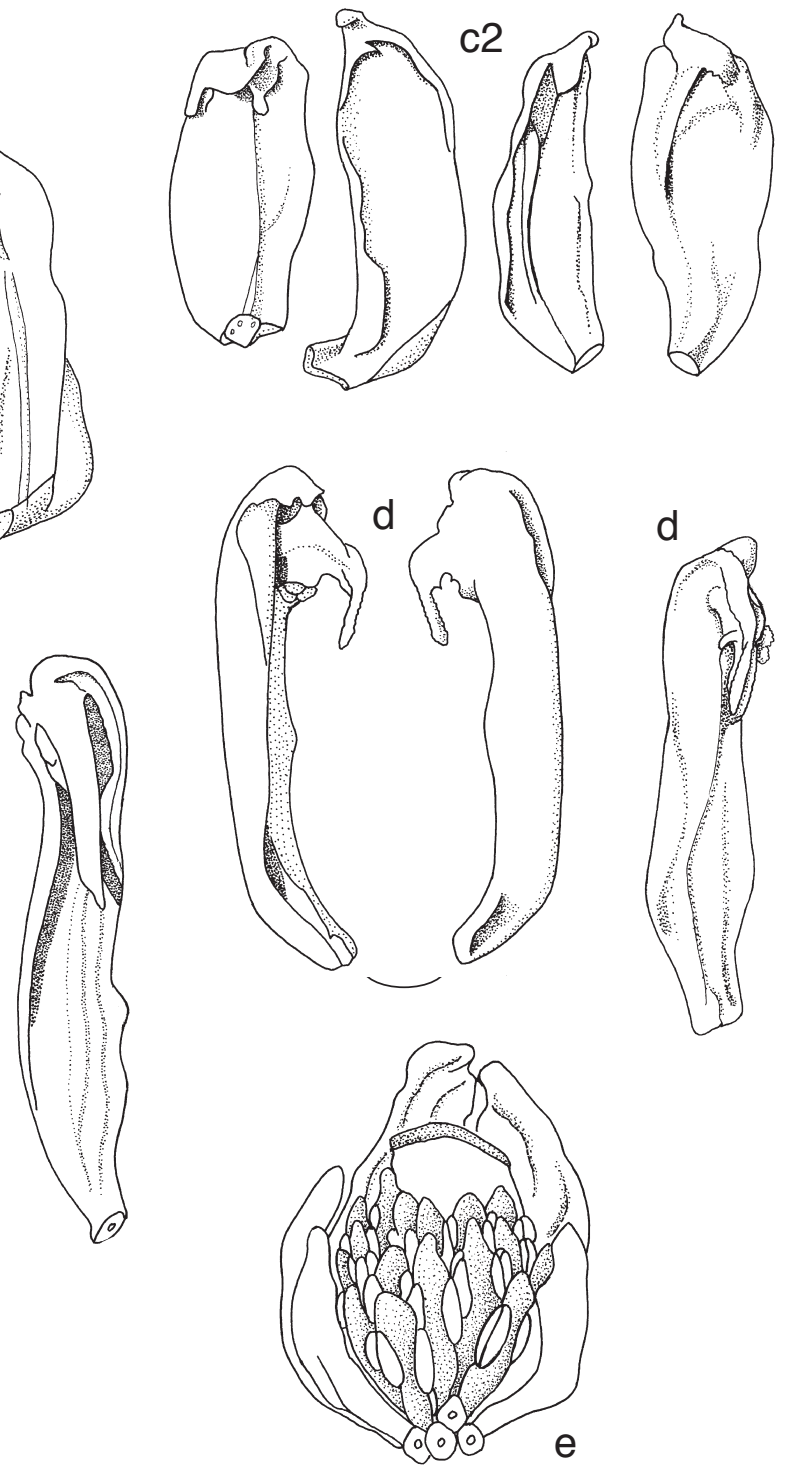

Fig. 1 Zygogynum haplopus (B.L.Burtt) Vink. a. Three generations of inflorescence at the top of a twig: scars (T1), old flowers and buds, resp.; Lf = leaf; b. open flower with erect inner petals: b1. small inner petal; b2. inner petal with adaxial apical thickenings; b3. very small petal with one theca; c. all petals from a just opening flower, adaxially: $c 1$. outer petals; $c 2$. inner petals; $d$. inner petals with extreme forms of adaxial thickenings, the smallest petal seen from both lateral sides; e. opened bud: two inner petals with adaxial apical thickenings overtop stamens and carpels (a: Brass 3063; b. NGF 45743; c: BSIP 4279; d: Brass 2959; e: Kajewski 1680). — Scale bars = $2 \mathrm{~mm}$. 

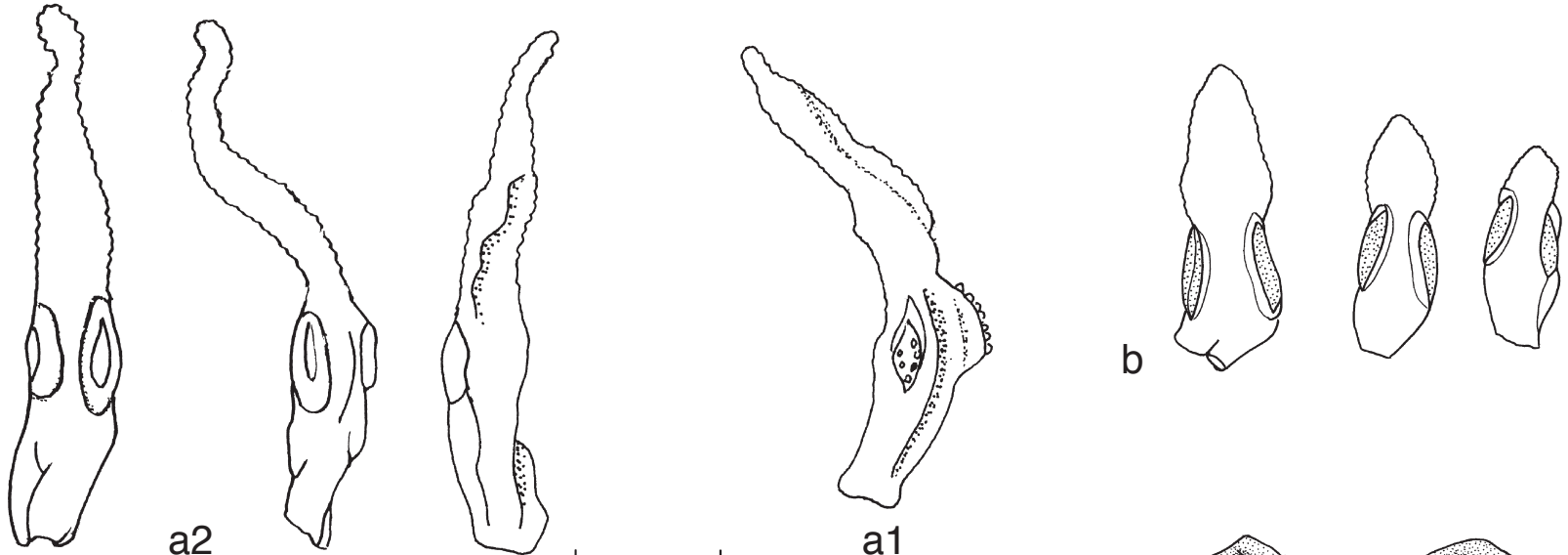

a2
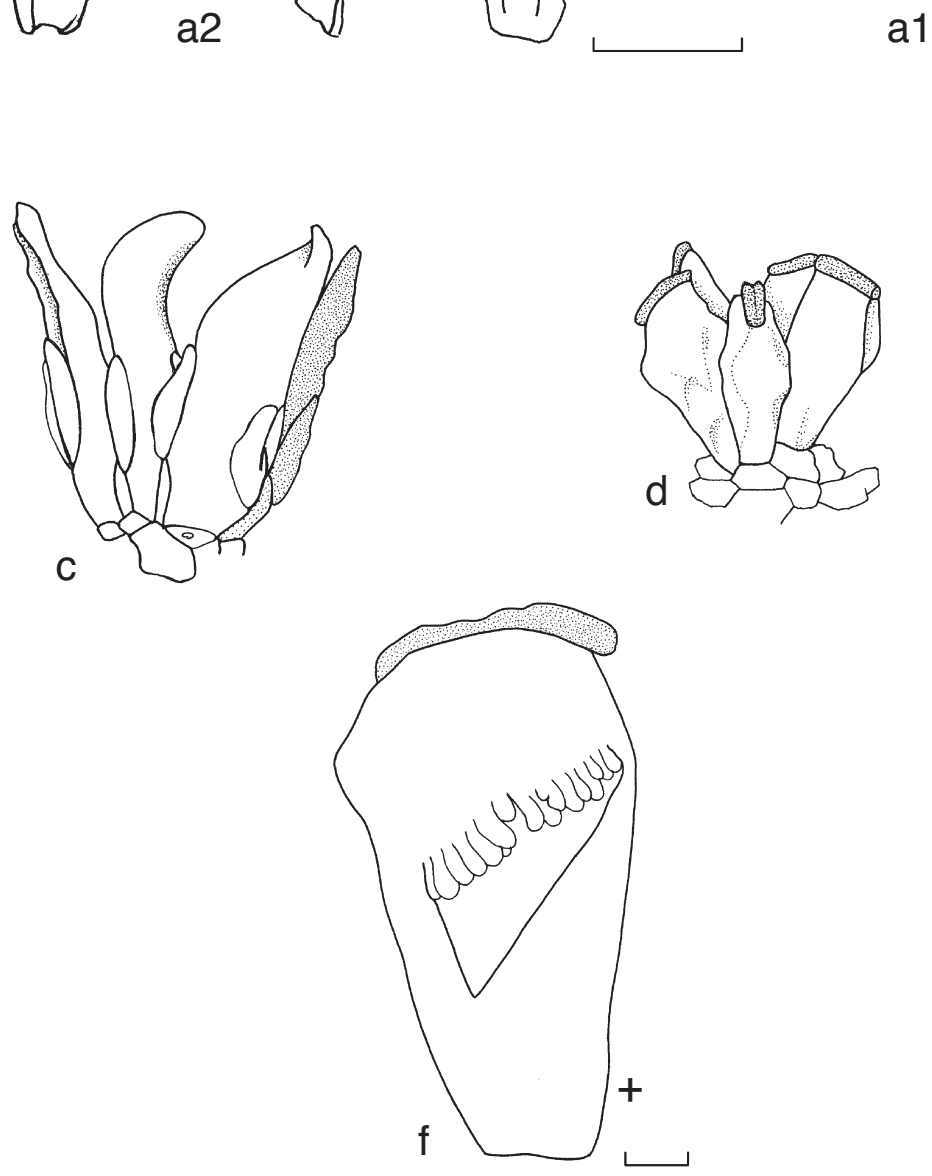

a1
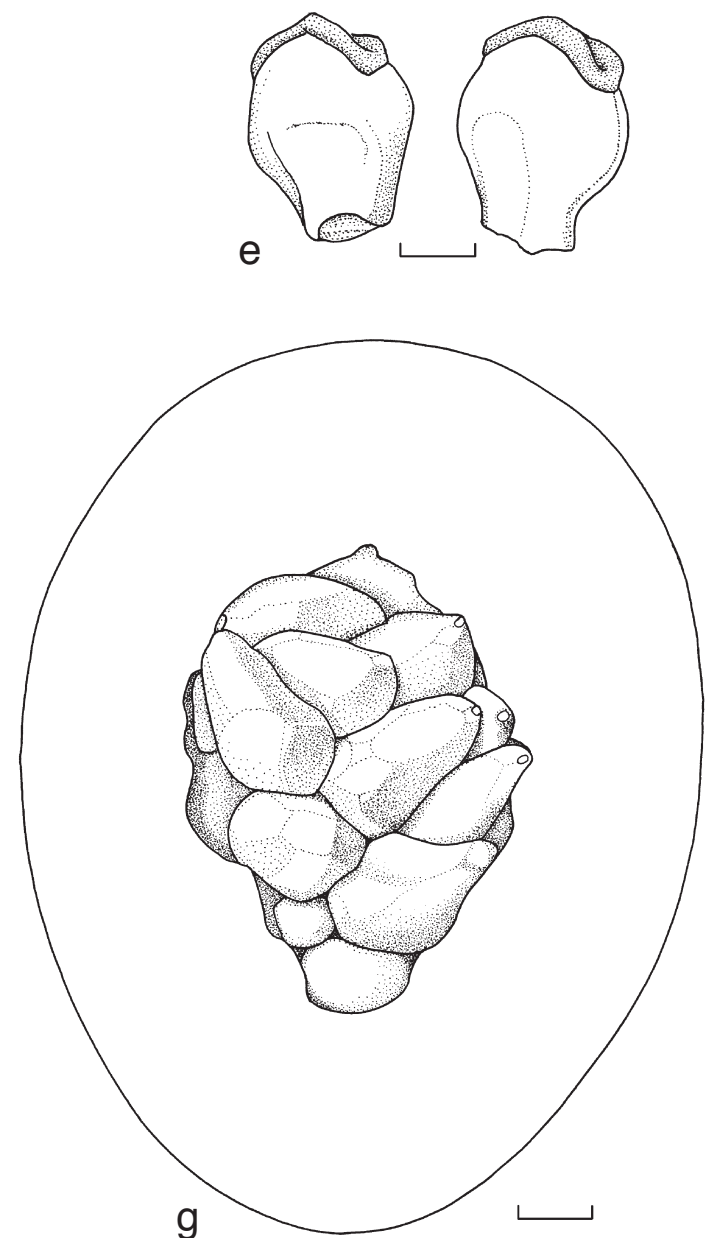

Fig. 2 Zygogynum haplopus (B.L.Burtt) Vink. a. Two mature slender stamens: a1. lateral; a2. abaxial, sublateral, and adaxial view, resp.; b. three mature broad stamens; lowest (left) middle and highest from the same flower; c. the stamen replacing a carpel is larger than the neighbouring stamens - from a bud; d. carpels, slender; e. carpels, broad; f. carpel from bud, longitudinal section - some ovules already pressed out of line; g. ripe fruit, opened, showing seeds (a, d. Brass 2959; b, e. Craven \& Schodde 307; c. RSS 1192; f. Corner RSS 41; g. BSIP 6418). - Scale bars: $a-e=2$ mm; f = 0.05 mm; g = 4 mm.

\section{TAXONOMY}

Although between populations there are definitely differences in the size ranges of several characters, there are no distinct gaps in the variations observed in the material at disposal, and the available specimens are accordingly considered to belong to a single species, Z. haplopus, except for a specimen from Guadalcanal: BSIP 12034. In vegetative characters and in most floral characters, e.g. the peculiar adaxial petal thickenings and the papillate stamens, this specimen falls distinctly within the variability of $Z$. haplopus. However, with only a single specimen available, the ranges of variability and distribution remain unknown, and as it deviates in three characters (branching in inflorescence, number of carpels, relative length of stigma), the choice has been made to describe it as a new species.

\section{Key}

1. Partial inflorescences 1-3-flowered. Carpels 1-8; stigma as long as carpel apex. . . . . . . . . . . . Z. haplopus

1. Partial inflorescences $6-8$-flowered. Carpels 10-13; stigma half as long as carpel apex . . . . . . . Z. whitmoreanum

Zygogynum haplopus (B.L.Burtt) Vink, comb. nov. — Fig. 1, 2

Bubbia haplopus B.L.Burtt (1936) sub t. 3315. - Belliolum haplopus (B.L.Burtt) A.C.Sm. (1942) 438, (1943b) 153; F.S.Walker (1948) 184; Whitmore (1966) 126, 132; Corner (1969) 576. - Type: Waterhouse $90(=b .743)$ (holo K; F). Belliolum burttianum A.C.Sm. (1942) 439, (1943b) 153, 154 f. 5. - Type: Kajewski 1680 (holo A; iso BISH).

Belliolum gracile A.C.Sm. (1942) 439, (1943b) 153. - Type: Brass 2898 (holo $\mathrm{A}$; iso $\mathrm{B}, \mathrm{BISH}$ ).

Belliolum kajewskii A.C.Sm. (1942) 440, (1943b) 153. — Type: Kajewski 2099 (holo $\mathrm{A}$; iso $\mathrm{BISH}, \mathrm{BO}$ ). 


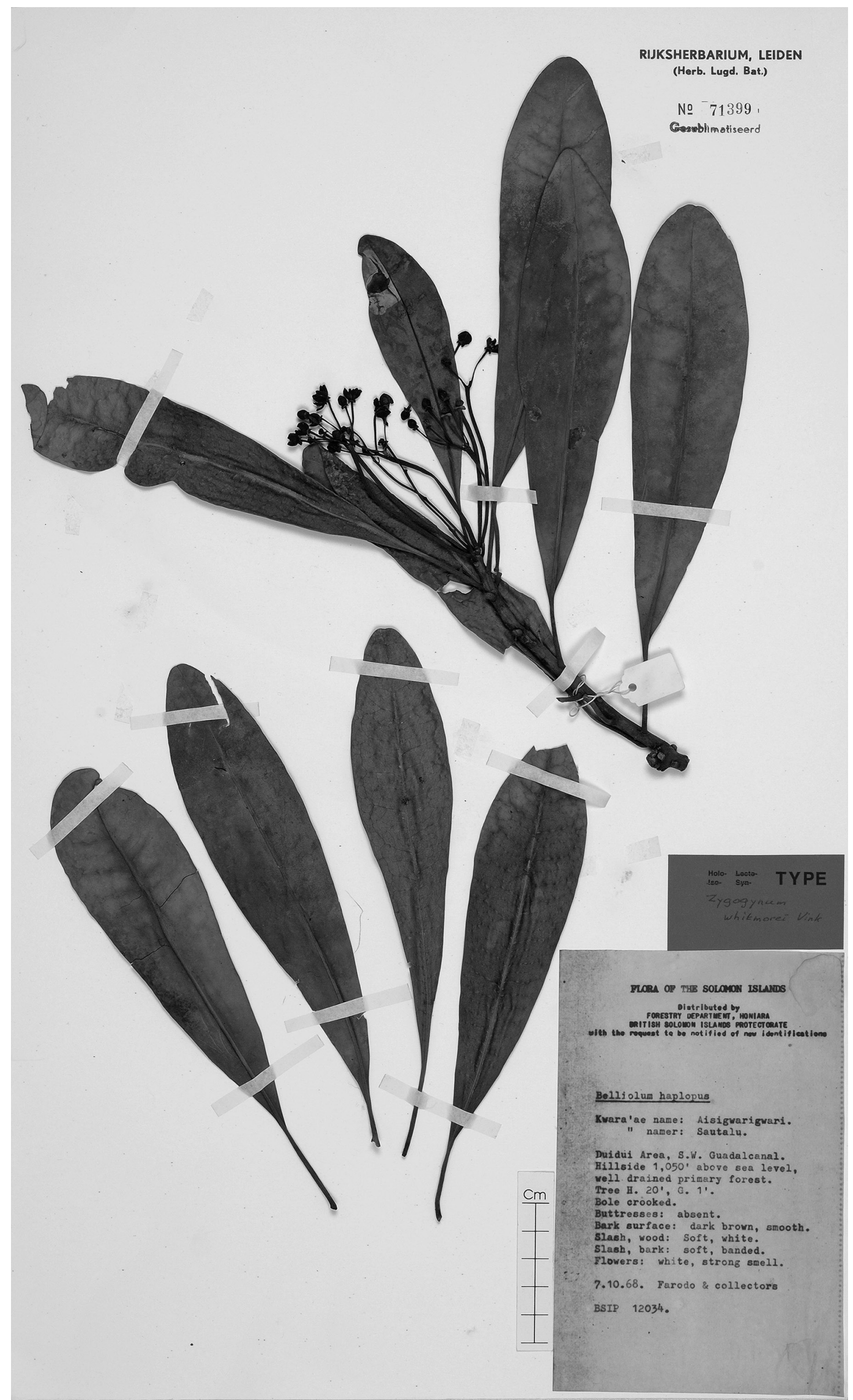

Fig. 3 Type specimen of Zygogynum whitmoreanum Vink (name corrected). 
Shrub or tree(let ) 3-18 $\mathrm{m}$ high and up to $20 \mathrm{~cm}$ d.b.h.; bark grey green to dark brown, smooth to fissured; wood white, cream- or pale (or dark) brown. Branchlets rather slender, (dark grey-) brown. Leaves scattered to dense at the end of branchlets; petiole 5-25(-33) mm long, shallowly grooved above, rounded below, dark brown to blackish; blade elliptic to (narrowly) obovate to oblanceolate, $4-26.5 \times 2-10 \mathrm{~cm}$, chartaceous, in sicco light brownish grey to brown below; apex obtuse to rounded, base (narrowly) acute (to shortly attenuate); midrib impressed above, prominent below; secondary nerves at $60-80^{\circ}$ with midrib, arcingly joined at some distance from the margin, distinct above, distinct to prominulous below. On lower leaf surface stomata white, solitary and/or in short strings or small clusters, also present over secondary nerves but often less dense there (or absent over thickest nerves); oil cells not apparent to dense and dark coloured. Inflorescences with 3-8 partial inflorescences, these $1.5-7.5 \mathrm{~cm}$ long, with rather slender axes but not pendulous, 1- or 1-3-flowered; empty bracts below inflorescence $0-4(-6)$; pedicels of solitary flowers 4-72 mm long, rather slender, in triads 4-40 mm long, slender, under fruit solid. Flowers scented. Calyx cup-shaped, $1-1.5 \mathrm{~mm}$ long, thin, smooth, margin with $2-3$ small tips and sometimes somewhat ruptured. Petals 7-22, outer ones elliptic to obovate, inner ones narrowly so, white, outer ones $5.5-13 \times$ (1.5-)2.2-6 mm, inner ones 4-10 × (0.8-)1-5 mm, (broadly) rounded, inner petals adaxially smooth, with longitudinal ribs, and/or apically with thickenings. Stamens 8-36, 2-3.5 mm long, except for thecae usually finely papillate, thecae lateral, sterile apex elliptic or ovate and rounded to (narrow-)triangular and acutish, $20-60 \%$ of length of stamen; pollen in tetrads. Carpels solitary or $1-8$, free, $2-3 \times 1.5-2 \times 0.8-1.3 \mathrm{~mm}$; stigma as long as the carpel apex or slightly longer at one or both ends, not descending adaxially; ovules 13-38. Fruitlets a rather hard berry, pink to red; ellipsoid to obovoid-globose, up to $15(-25) \mathrm{mm}$ diam, stipe absent or rather slender and up to 2(-5) mm long, stigma apical, 3-6 mm long. Pericarp 2-7 mm thick, with nests of brachysclereids, said to taste hot peppery; pulpa almost not developed. Seeds 5-36, light greyish brown (black when immature), narrowly obovoid, on faces towards each other flat and smooth, convex free surface with very fine ribs and pustules, up to $6 \times 4 \times 3.5 \mathrm{~mm}$.

Distribution - Solomon Islands, from Bougainville I. to San Christoval I. (no collections seen from Malaita).

Habitat \& Ecology — Primary or disturbed lowland, hillside, or ridgetop forest, at 0-1900 m altitude (the single collection above $1700 \mathrm{~m}$ is Kajewski 2630, see Folklore). Flowering and fruiting throughout the year, but ripe fruits mostly in August.

Vernacular names - Kwara'ae language: Aisigwarigwari (sometimes erroneously Aibosbos, the name of Psychotria ssp.); other names: Mahuisihuisi, Mamamoto, Ororojenari, Ororfoyu, Paru, Ses-a-vere.

Folklore - Kajewski (2630) reports from Tutuve Mountain on Guadalcanal Island that at $1900 \mathrm{~m}$ this tree ('leas-a-vera') is planted in taro gardens to make the taro grow well (flourish).

Etymology of the generic name Bubbia. Philippe-Dominique van Tieghem died from yellow fever on 6 January 1839, during a business visit to Martinique. Three months later, on 19 April, at Bailleul in France, his wife Amélie Bubbe gave birth to a son who was named Philippe Édouard Léon. Soon after, Amélie also succumbed. The orphan was first taken care of by his aunt and uncle Stéphanie and Napoléon Bubbe, both unmarried, and later on by his sisters (Costantin 1914). As a scientist, he became known by his first name. Philippe van Tieghem apparently honoured his mother and her family by naming a new genus in the Winteraceae as Bubbia.

More recently two alkaloids obtained from Zygogynum pauciflorum from New Caledonia were named bubbialine and bubbialidine (Ahond et al. 1990). The latter is also found in Phyllanthus amarus (Euph.) (Nahar et al. 2011: 122).

\section{Zygogynum whitmoreanum Vink, sp. nov. — Fig. 3}

Zygogyno haplopus carpellis numerosis (10-13) et inflorescentiis partialibus 6-8-floribus differt. - Typus: Farodo BSIP 12034 (L).

Etymology. This species is named after Dr. Timothy Charles Whitmore (1935-2002), from 1962 till 1964 Forest Botanist at Honiara; see Flora Malesiana I, 5, 1958, CCCXXXII, and I, 8, 1974, CV; Turner 2002; Grubb et al. 2003.

Treelet $6 \mathrm{~m}$ high with crooked bole $10 \mathrm{~cm}$ diam; bark dark brown, smooth; wood white, soft. Branchlets rather slender, brown. Leaves scattered along branchlets; petiole 15-25 mm long, rounded but distally shallowly grooved above, brown; blade oblanceolate, $15-17 \times 3.5-4 \mathrm{~cm}$, chartaceous, in sicco light brown below; apex (narrowly) rounded (or minutely retuse), base unequal, narrowly acute; midrib impressed above, rounded below; secondary nerves at $65-75^{\circ}$ with midrib, arcingly joined at some distance from the margin, distinct on either side. On lower leaf surface stomata white, solitary, dense, also present over secondary nerves; oil cells many, dark to hardly visible. Inflorescences with 9 partial inflorescences, these $6-8.5 \mathrm{~cm}$ long, with rather slender axes but not pendulous, 6-8-flowered; empty bracts below inflorescence absent; pedicels 8-17 mm long, slender. Flowers strongly scented. Calyx subrotate, $1 \mathrm{~mm}$ long, thin, smooth, margin with 2 small tips. Petals 14, white, outer ones obovate and broadly rounded, $7 \times 3.5 \mathrm{~mm}$, next higher ones $5.5-6.5 \times 2-2.3 \mathrm{~mm}$, inner ones narrowly obovate to oblanceolate and rounded, adaxially with apical thickenings, $4.3-5 \times 1-1.5 \mathrm{~mm}$. Stamens 23-27, 3-4 mm long, except for thecae finely papillate, thecae lateral, sterile apex lingulate to narrowly triangular, $30-50 \%$ of length of stamen. Carpels $10-13$, free, $2.3 \times 1 \mathrm{~mm}$; stigma short (about half as long as carpel width), variably steep on adaxial side of carpel apex; ovules 9-13. Fruits not seen.

Distribution - Only known from the type: Duidui, SW Guadalcanal, Solomon Islands.

Habitat \& Ecology — Primary forest on hillside, $315 \mathrm{~m}$ altitude. Flowering October.

Vernacular name - Kwara'ae language: Aisigwarigwari (the same name as for Z. haplopus).

\section{REFERENCES}

Ahond A, Guilhem J, Hamon J, et al. 1990. Bubbialine et bubbialidine, alcaloïdes nouveaux extraits de Zygogynum pauciflorum. Journal of Natural Products 53: 875-881.

Bailey IW, Nast CG. 1943a. The comparative morphology of the Winteraceae. - I. Pollen and stamens. Journal of the Arnold Arboretum 24: 340-346. Bailey IW, Nast CG. 1943b. The comparative morphology of the Winteraceae. - II. Carpels. Journal of the Arnold Arboretum 24: 472-481.

Burtt BL. 1936. Bubbia haplopus B.L. Burtt. Winteraceae. Hooker's Icones Plantarum 34: t. 3315, 1-3.

Canright JE. 1952. The comparative morphology and relationships of the Magnoliaceae. I. Trends of specialization in the stamens. American Journal of Botany 39: 484-497.

Carlquist S. 1983. Wood anatomy of Belliolum (Winteraceae) and a note on flowering. Journal of the Arnold Arboretum 64: 161-169.

Corner EJH. 1969. Mountain flora of Popomanaseu, Guadalcanal. Philosophical Transactions of the Royal Society of London B, 255: 575-577.

Costantin J. 1914. Philippe van Tieghem. Annales des Sciences Naturelles, Botanique, serie 9, 19: I-VIII.

Endress PK. 1980. The reproductive structures and systematic position of the Austrobaileyaceae. Botanische Jahrbücher für Systematik, Pflanzengeschichte und Pflanzengeographie 101: 393-433.

Endress PK, Doyle JA. 2009. Reconstructing the ancestral flower and its initial specializations. American Journal of Botany 96: 22-66.

Endress PK, Hufford LD. 1989. The diversity of stamen structures and dehiscence patterns among Magnoliidae. Botanical Journal of the Linnean Society 100: 45-85.

Friis EM, Crane PR, Pedersen KR. 1986. Floral evidence for Cretaceous chloranthoid angiosperms. Nature 320: 163-164. 
Godley EJ, Smith DH. 1981. Breeding systems in New Zealand plants 5. Pseudowintera colorata (Winteraceae). New Zealand Journal of Botany 19: 151-156.

Gottsberger G, Silberbauer-Gottsberger I, Ehrendorfer F. 1980. Reproductive biology in the primitive relic angiosperm Drimys brasiliensis (Winteraceae). Plant Systematics and Evolution 135: 11-39.

Grubb PJ, Swaine MD, Turner IM. 2003. Preface - A tribute volume for the late Dr T.C. Whitmore. Perspectives in Plant Ecology, Evolution and Systematics 6: 1-3.

Hofmeister W. 1868. Allgemeine Morphologie der Gewächse. Engelmann, Leipzig.

Kajewski SF. 1946. Plant collecting in the Solomon Islands. Journal of the Arnold Arboretum 27: 291-304.

Kirchoff BK. 2003. Shape matters: Hofmeister's rule, primordium shape, and flower orientation. International Journal of Plant Sciences 164: 505-517.

Leins P, Erbar C. 1997. Floral developmental studies: some old and new questions. International Journal of Plant Sciences 158 (6 Suppl.): 3-12.

Lloyd DG, Wells MS. 1992. Reproductive biology of a primitive angiosperm, Pseudowintera colorata (Winteraceae), and the evolution of pollination systems in the Anthophyta. Plant Systematics and Evolution 181: 77-95.

Maas PJM, Westra LYT. 2003. Revision of the neotropical genus Pseudoxandra (Annonaceae). Blumea 48: 201-259.

Mols JB, Keßler PJA. 2003. The genus Miliusa (Annonaceae) in the AustroMalesian area. Blumea 48: 421-462.

Nahar L, Sarker SD, Delazar A. 2011. Phytochemistry of the genus Phyllanthus. In: Kuttan R, Harikumar KB (eds), Phyllanthus species: scientific evaluation and medicinal applications. CRC Press, Boca Raton, Florida.

Pellmyr O, Thien LB, Bergström G, et al. 1990. Pollination of New Caledonian Winteraceae: opportunistic shifts or parallel radiation with their pollinators? Plant Systematics and Evolution 173: 143-157.

Sampson FB, Tucker SC. 1978. Placentation in Exospermum stipitatum (Winteraceae). Botanical Gazette 139: 215-222.

Scott RM, Heyligers PB, McAlpine JR, et al. 1967. Lands of Bougainville and Buka Islands, territory of Papua and New Guinea. C.S.I.R.O. Land Research Series 20. C.S.I.R.O., Melbourne.

Smith AC. 1942. Studies in Papuasian plants. V. Journal of the Arnold Arboretum 23: 417-443.

Smith AC. 1943a. The American species of Drimys. Journal of the Arnold Arboretum 24: 1-33.

Smith AC. 1943b. Taxonomic notes on the Old World species of Winteraceae. Journal of the Arnold Arboretum 24: 119-164.

Thien LB. 1980. Patterns of pollination in the primitive Angiosperms. Biotropica 12: 1-13.

Thien LB, Pellmyr O, Yatsu LY, et al. 1990. Polysaccharide food-bodies as pollinator rewards in Exospermum stipitatum and other Winteraceae. Bulletin du Muséum National d'Histoire Naturelle Paris IV, 12, section B, Adansonia no 2: 191-197.
Thompson RB, Hackman BD. 1969. Some geological notes on areas visited by the Royal Society Expedition to the British Solomon Islands, 1965. Philosophical Transactions of the Royal Society of London B, 255: 189-202.

Tucker SC. 1959. Ontogeny of the inflorescence and the flower in Drimys winteri var. chilensis. University of California Publications in Botany 30: 257-336.

Tucker SC. 1965. Terminal carpel initiation in Drimys. American Journal of Botany 52: 624.

Turner IM. 2002. T.C. Whitmore 1935-2002. Folia Malaysiana 3: 31-43.

Vink W. 1970. The Winteraceae of the Old World. I. Pseudowintera and Drimys - Morphology and taxonomy. Blumea 18: 225-354.

Vink W. 1977. The Winteraceae of the Old World. II. Zygogynum - Morphology and taxonomy. Blumea 23: 219-250.

Vink W. 1983. The Winteraceae of the Old World. IV. The Australian species of Bubbia. Blumea 28: 311-328.

Vink W. 1985. The Winteraceae of the Old World. V. Exospermum links Bubbia to Zygogynum. Blumea 31: 39-55.

Vink W. 1993. Winteraceae. Flore de la Nouvelle-Calédonie 19: 90-171.

Walker FS. 1948. The forests of the British Solomon Islands Protectorate. Crown Agents, London.

Whitmore TC. 1966. Guide to the forests of the British Solomon Islands. Oxford University Press.

\section{IDENTIFICATION LIST}

Zygogynum whitmoreanum: BSIP 12034.

Zygogynum haplopus:

Brass 2898, 2959, 3063, 3063A, 6244 - BSIP 154, 894, 951B, 1000, 1240 1435, 1903, 1952, 2060, 2065, 2118, 2386, 2509, 2514, 2537, 3117, 3201 , $3610,3751,4279,5152,5935,6374,6418,6625,6813,7182,7207,7448$ $7794,8329,8525,8589,8606,9542,9840,10984,11015,11479,11649$, 12555, 12823, 16308, 17580, 18343, 18548, 18923, 18984, 19355.

Comins 136 - Craven \& Schodde 99, 261, 307.

Kajewski 1658, 1680, 1994, 2007, 2099, 2574, 2630.

NGF 31343, 45689, 45743.

Regalado \& Sirikolo 776 - R.S.S. (Corner) 41, 1192, 1196; (Whitmore) 6110, 6233.

Schodde \& Craven 3718.

Voyce 3.

Waterhouse 90, B537, B743. 